\title{
The thrill of the chase: uncovering illegal sport hunting in Brazil through YouTube ${ }^{\mathrm{TM}}$ posts
}

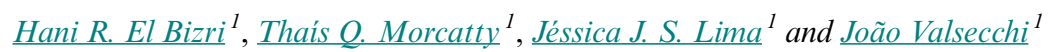

\begin{abstract}
The impacts of unregulated sport hunting can severely affect populations of target game species. Because hunting in Brazil is limited by law, obtaining data on illegal sport hunting in this country is challenging. We used an unusual online resource, YouTube ${ }^{\mathrm{TM}}$, to detect the occurrence of sport hunting in Brazil, measure the impacts of the activity on the main Brazilian game species and biomes, evaluate the opinions of hunters and internet users on sport hunting, and discuss the need for policy interventions in wildlife conservation in this country. We found 383 videos related to Brazilian sport hunting on YouTube ${ }^{\mathrm{TM}}$, accounting for more than 15 million views. Most videos were produced in the Cerrado (Brazilian savannah) and approximately $70 \%$ of them depicted events of pursuit and killing of wild animals, especially lowland pacas (Cuniculus paca) and armadillos (Family Dasypodidae). Videos were posted primarily in July and December, coinciding with the two main Brazilian vacation periods. Furthermore, the shotguns identified on videos show that sport hunters expend large sums of money to undertake their hunts. These results indicate that Brazilian sport hunters are possibly wealthier urban residents who travel to rural areas to hunt, contrasting with previous hunting studies in the country. Most viewers declared themselves in favor of sport hunting in comments $(n=2893)$ and ratings $(n=36,570)$ of the videos. Discussions generated by comments suggest that Brazilian sport hunters employ several informal management strategies to maintain game species stocks for future hunting and intensely question the restrictions of Brazilian environmental policies. Our results demonstrate that solutions are needed for the regulation of sport hunting in Brazil. Government actions, whether to increase surveillance or legalize hunting programs, should take into account the opinions of sport hunters and their perceptions on hunting dynamics to support effective policy decisions on wildlife conservation in Brazil.
\end{abstract}

Key Words: bushmeat; conservation; mammals; public opinion

\section{INTRODUCTION}

Hunting activity is reported in all inhabited regions of the world and is primarily described as an important source of food for inhabitants of rural areas (Nasi et al. 2011). The consumption of bushmeat by these populations is often recognized as their main way of obtaining protein for subsistence (Redford 1992). In contrast, human population growth, the increased accessibility of remote areas, and improvement in hunting techniques in the last decades have resulted in a remarkable intensification of the harvest rate of wild animals for consumption and trade (Fa and Yuste 2001, Nasi et al. 2008). Thus, despite its sociocultural importance, hunting has been identified as one of the main drivers of global biodiversity loss (Fa et al. 2002).

With the goal of mitigating the negative effects of hunting around the world, studies and policies seek innovations to promote alternative food and income sources for rural populations (Milner-Gulland et al. 2003, Nasi et al. 2008). However, other motivations for hunting are rarely considered in resolving the impacts of this activity. Sport hunting, for example, may contribute considerably to the decline of game species' populations, especially when not properly regulated. Unlike subsistence hunting, the motivations for practicing sport hunting are guided primarily by the thrill of chasing and killing animals (Loveridge et al. 2006). Because of its cultural features that are not linked to the need for food, sport hunting elicits divided opinions among conservationists.

The most socially acceptable type of sport hunting in the world is hunting to manage populations of introduced or native species undergoing uncontrolled population growth (e.g., Henderson et al. 2000). Another common type of sport hunting in North
America aims at obtaining trophies, such as horns, skulls, and teeth, which are collected by the hunters. In 1991 alone, regulated trophy hunting generated more than US\$35 billion in the United States (Jackson 1996).

In Africa, programs for sport hunting of wildlife were developed in 23 countries as a strategy for generating income for rural communities (Lindsey et al. 2007a). In most cases, hunters are foreign tourists from Europe and the United States who pay to kill specimens of African fauna and consume the meat obtained. One successful example of sport hunting in Africa is the Communal Areas Management Programme for Indigenous Resources (CAMPFIRE) in Zimbabwe. Approximately $90 \%$ of total income generated by this project arises from sport hunting, and at least $50 \%$ of the profit is returned to the rural communities involved (Mutandwa and Gadzirayi 2007).

In addition to income generation, several studies report population recovery of wild game species due to increased investment in conservation from the revenue earned from the sport hunting (Leader-Williams and Hutton 2005, Gandiwa et al. 2013). Lindsey et al. (2007b) also reports that sport hunting has motivated the protection of habitats in Africa, where cattle breeding farms are restoring native vegetation so they can be converted into game farms.

In contrast, Yasuda (2012) describes a case of inadequate public management associated with sport hunting in Cameroon. To increase the availability of animals for tourism hunters, communities involved in a governmental sport-hunting project were prohibited from hunting various game species, generating conflicts, migrations, and the imprisonment of local residents. Weber et al. (2006) also suggest that hunting programs in Mexico 
Fig. 1. Timeline of the creation of legislation regulating hunting activity in Brazil.

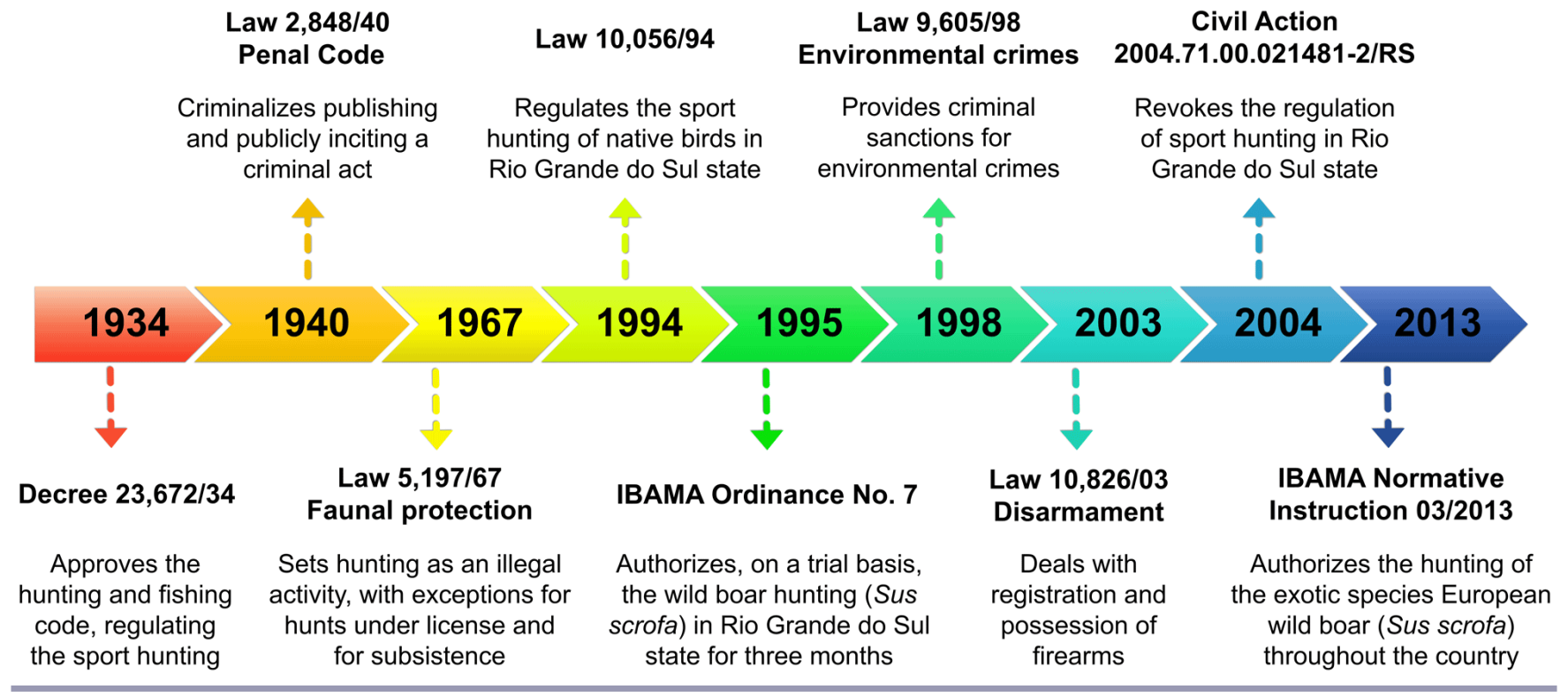

are promoting severe impacts on wildlife populations, especially because of serious difficulties in maintaining proper infrastructure, personal training, and sustainability assessments. Additionally, Loveridge et al. (2006) describe the impacts of trophy hunting in the United States on the behavior of wild animals, reporting that hunting affects the animals' natural movement patterns in Yellowstone National Park.

In contrast with the strategies adopted in North America, Europe, and Africa, many countries in South America keep protectionist policies in relation to sport hunting, such as the reduced number of species permitted for hunting or the total banishment of the activity (Pérez and Ojasti 1996). In Brazil, the largest country of Latin America, hunting was legalized in the past. Through a law approved in 1934 (Law No. 23,672/34), sport hunting became an important cultural practice in the country (Fernandes-Ferreira and Alves 2014). During some decades, hunters were often involved in wildlife conservation efforts and in the creation of reserves. However, the Brazilian government approved, in 1967, the wildlife protection law (Law No. 5,197/67), which criminalized the hunting of wild animals throughout the country and the trade of wildlife products (Fig. 1).

Despite these restrictions, Brazilian legislation has decreed that sport hunting can be carried out when scientific studies and actions of environmental agencies identify species to be hunted and support the practice. However, although there are some detailed studies on the biology of some Neotropical game species (e.g., Mayor et al. 2013), Brazilian environmental agencies seldom generate hunting programs, especially with regard to native wild species (Pinheiro 2014).

The only program of sport hunting of native species developed in Brazil was approved in the state of Rio Grande do Sul and permitted the hunting of waterfowl, tinamous, and pigeons (Guadagnin et al. 2007). However, hunting in this state was definitively repealed just five years later (Nassaro 2011).
Conversely, the hunting of European wild boar (Sus scrofa), an invasive alien species in Brazil, is currently authorized for population control and the reduction of environmental and economic damage (Normative Instruction IBAMA 03/2013; Deberdt and Scherer 2007). Nonetheless, the distribution of this species is limited, and obtaining permits for the activity is quite complex, especially with respect to obtaining a firearms license. Possession of firearms in Brazil is only allowed for police officers, security servers, residents of rural areas that depend solely on the gun to provide food for their families, and members of shooting clubs (Law No. 10,826/2003). Complying with the requirements of the law is bureaucratic and financially costly, which facilitates the permanence of hunting irregularities.

For example, the Brazilian federal environmental agency (IBAMA) recorded 2969 infractions against wildlife in Brazil in 2010 (Brasil 2015), and although there is no detailed information on each event, many of these infractions are probably illegal sport hunting occurrences in the country. The permanence of sport hunting of wild species in Brazil is also suggested by some studies. Alves et al. (2009) showed that $77 \%$ of the hunters in northeastern Brazil hunt for sport. Sampaio (2011) also demonstrated that hunters in the state of Rio de Janeiro, southeastern Brazil, value the practice of sport hunting and yearn to consume the meat of wild animals. Moreover, some studies expose evidence of the presence of sport hunting in strictly protected reserves (e.g., Chiarello 2000, Cullen et al. 2001) and of hunting in peri-urban forested areas (van Vliet et al. 2015).

The appreciation for the practice of sport hunting in Brazil is probably due to the country's recent urbanization process (Deák and Schiffer 1999). Only 40 years have passed since the number of urban inhabitants exceeded the number of rural residents in Brazil (IBGE 2011). The recent migration of people from rural areas to urban centers allowed for the maintenance of cultural links with the rural practices, thus even urban residents in Brazil remain engaged in hunting activities (van Vliet et al. 2014). 
Table 1. The eight mammalian taxa most often cited as hunting targets in Brazil, the search keys created to find Brazilian sport hunting videos posted on Youtube ${ }^{\mathrm{TM}}$, and the number of videos found over the results pages for each search key.

\begin{tabular}{|c|c|c|c|c|c|c|c|c|}
\hline \multirow[t]{2}{*}{ Taxon } & \multirow[t]{2}{*}{ Common name } & \multirow[t]{2}{*}{ Search key } & \multicolumn{2}{|c|}{ Videos of target taxa } & \multirow{2}{*}{$\begin{array}{l}\text { Additio- } \\
\text { nal taxa }\end{array}$} & \multirow[t]{2}{*}{ Instr. } & \multirow[t]{2}{*}{ Advert. $^{\S}$} & \multirow[t]{2}{*}{ TOTAL } \\
\hline & & & $\begin{array}{c}\text { Successful } \\
\text { trip }\end{array}$ & $\begin{array}{c}\text { Unsuccessful } \\
\text { trip }\end{array}$ & & & & \\
\hline \multicolumn{9}{|l|}{ PERISSODACTYLA } \\
\hline Tapirus spp. & tapirs & "caça" + "anta" & 4 & 6 & 36 & 3 & 9 & 58 \\
\hline \multicolumn{9}{|l|}{ ARTIODACTYLA } \\
\hline Family Cervidae & deer & "caça" + "veado" & 10 & 7 & 5 & 12 & 2 & 36 \\
\hline Tayassu pecari & white-lipped peccary & "caça" + "queixada" & 4 & 0 & 41 & 10 & 9 & 63 \\
\hline Pecari tajacu & collared peccary & "caça" + "catitu" & 14 & 7 & 40 & 17 & 9 & 87 \\
\hline \multicolumn{9}{|l|}{ RODENTIA } \\
\hline Hydrochoerus hydrochaeris & capybara & "caça" + "capivara" & 11 & 11 & 19 & 17 & 0 & 58 \\
\hline Cuniculus paca & lowland paca & "caça" + "paca" & 19 & 19 & 19 & 29 & 4 & 90 \\
\hline Dasyprocta spp. & agoutis & "caça" + "cutia" & 11 & 10 & 25 & 33 & 3 & 82 \\
\hline \multicolumn{9}{|l|}{ CINGULATA } \\
\hline Family Dasypodidae & armadillos & "caça" + "tatu" & 31 & 13 & 6 & 30 & 2 & 82 \\
\hline TOTAL & & & 103 & 74 & 187 & 153 & 39 & 556 \\
\hline
\end{tabular}

Most studies on hunting in Brazil have focused on subsistence and medicinal uses of wildlife, especially by rural populations in the north and northeast (e.g., Peres 2000, Alves 2009, Alves and Souto 2011, Morcatty and Valsecchi 2015). Comparatively, there are few studies that deal with sport hunting in the country and, in general, these studies address this issue superficially (e.g., Chiarello 2000), mainly because of the difficulties faced by researchers in obtaining information because of the illegality of this activity (Alves and Souto 2011). Thus, detailed information on the effects of illegal sport hunting and its magnitude in Brazil are still necessary to improve regulatory and conservation measures.

In this context, the internet has the potential to contribute to the access to information on restricted topics such as illegal sport hunting. Online data are widely used by economists and epidemiologists in their research, but they are still rarely exploited in conservation studies (Proulx et al. 2014). YouTube ${ }^{\mathrm{TM}}$ is one of the most popular websites used to share videos online and has become an important forum for the exchange of public opinion. Nekaris et al. (2013) discuss the role of YouTube ${ }^{\mathrm{TM}}$ in stimulating the misuse of wildlife based on an assessment of a viral video on the hunting and international trafficking of the threatened slow lorises (Nycticebus spp.), providing an example of how assessing YouTube $^{\mathrm{TM}}$ data can be useful for identifying challenges in conservation and to monitor illicit acts against wildlife. Similarly, we identified many videos of sport hunting practiced by Brazilian citizens posted on YouTube ${ }^{\mathrm{TM}}$; these videos constitute an important database to fill the knowledge gaps regarding this activity in Brazil.
In the present study, we used online data from YouTube ${ }^{\mathrm{TM}}$ (i) detect whether illegal sport hunting still occurs in Brazil and its coverage in the country; (ii) gain insight into the profile of Brazilian sport hunters, their motivations, and the risks identified for the activity; (iii) estimate sport hunting intensity and impacts on the main Brazilian game species and biomes; (iv) assess the opinions of internet users regarding sport hunting in Brazil; and (v) discuss the infractions to legislation made by sport hunters on YouTube $^{\mathrm{TM}}$ and the possible measures to be taken to minimize the impacts of unregulated sport hunting in Brazil.

\section{METHODS}

\section{Data collection}

We performed an extensive literature review and consulted 104 research documents, i.e., articles, theses, dissertations, book chapters, technical reports, conference papers, to identify the eight mammalian taxa most often cited as hunting targets in Brazil (Appendix 1). Thereafter, we created search keys with which to locate videos of hunting activity targeting these eight taxa on YouTube $^{\mathrm{TM}}$ (Table 1).

We created the search keys using the terms "caça" (meaning "hunting" in Portuguese) and the Portuguese common name of the species or taxonomic group of interest, for example, "tatu" for armadillos (Family Dasypodidae), using quotes for both words and a sum signal to stitch them together (Table 1). We conducted the searches between July and December 2014. For each search key, we watched 20 videos from 10 results pages generated by YouTube ${ }^{\mathrm{TM}}$, totaling 200 videos analyzed per taxon 
and 1600 videos in total. In this study, the taxa included in the search keys are referred to as target taxa, whereas other taxa not included in the search keys but occasionally found in videos are designated as additional taxa, i.e., mammals not included in search keys, birds and reptiles. We considered only videos produced by Brazilians for subsequent analysis. Because internet access for the rural poor is uncommon in Brazil - around $80 \%$ of the poorest Brazilian citizens do not use internet, and also $85 \%$ of rural inhabitants in Brazil do not have internet access (Brasil 2014) — we considered every video that featured noticeably nonindigenous hunting practices as a Brazilian sport hunting video.

We gathered specific information on the sharing and viewing of each video identified to address sport hunting by Brazilians. We recorded the uploader's nickname, the number of views, the date of posting, and, when available, the location of video production, i.e., city and state of Brazil or foreign country, provided by the uploader or hunter in the video. We classified the videos into three categories according to their purpose, which included (i) hunting events: videos demonstrating attempts to capture or kill specimens by the hunter; (ii) instruction: videos providing instruction on the use of techniques and materials for hunting or disseminating opinions and news on sport hunting in Brazil; and (iii) advertisements: videos featuring accessories, weapons, and hunting dogs for sale. For videos portraying hunting events, we recorded whether they were successful, i.e., resulted in the capture or killing of animals, or unsuccessful, i.e., no capture or killing, the taxa pursued, and whether the species were target or additional taxa. Because firearms legislation is very restrictive in Brazil, we also collected information on the types of shotguns used during the hunting events.

To understand the opinions of viewers and commentators regarding sport hunting in Brazil, we recorded the number of ratings in each YouTube ${ }^{\mathrm{TM}}$ category, i.e., likes and dislikes offered by the viewers, and compiled information from the first 20 comments received by each video after the posting date. We classified each comment as being either for or against sport hunting. For comments in favor of the activity, we used six categories to classify them: (i) compliments regarding the hunting event; (ii) critiques of the hunting event (note that the critique is targeted at the event and not at the practice of hunting); (iii) mentions of a personal hunting experience; (iv) questions for or requests to the uploader; (v) suggestions for improvement of the techniques used by the hunter; and (vi) broad discussions in favor of hunting in Brazil. We also used four categories to classify comments against sport hunting: (i) claims that the event is an act of cruelty or immorality; (ii) claims of the event's illegality; (iii) citations of Brazilian laws and infractions committed by the hunter; and (iv) broad discussions against hunting in Brazil.

Additionally, we identified possible informal hunting management rules adopted by sport hunters in Brazil, as cited in the speeches made by hunters in the videos or in comments from uploaders and commentators. Because many of the commentators declared themselves to be sport hunters, we also identified the main topics of discussion in the comments to reveal the leading motivations of sport hunters for the activity, the risks identified by them, and their complaints about hunting legislation in Brazil.

\section{Data analysis}

We used descriptive statistics and hypothesis tests to determine the sharing and viewing patterns of sport hunting videos in Brazil. As a measure of the minimum number of active sport hunters in the country, we counted the number of independent uploaders who published hunting videos as well as the average number of videos posted per uploader. We summed the number of views of all videos found and used this value as an indicator of the potential attraction of sport hunting videos in Brazil. We estimated the frequency of sport hunting videos released per year and performed correlation tests to assess trends in postings over time. We also estimated the number of videos portraying hunting events released per month to assess a possible seasonality in sport hunting activity in Brazil. We calculated the frequency of videos found by YouTube ${ }^{\mathrm{TM}}$ 's theme category, a classification chosen by the uploader when posting the video. To assess possible strategies adopted by hunters to avoid surveillance, we calculated the frequency of uploader's nicknames showing personal names and the frequency of hunting events in which the hunters showed their own faces. In addition, we compared the number of videos in which the hunter used firearms with those in which they used other kinds of shotguns, i.e., air pressure carbines.

To calculate the impacts of hunting on the target species, we calculated the cumulative number of hunting event videos of target taxa found in the first 10 results pages generated by YouTube $^{\mathrm{TM}}$ and performed linear and logarithmic correlation tests to assess the growth trends of videos for each taxon. In addition, we calculated the frequency of additional taxa found in the search results.

Additionally, based on forest coverage criteria presented by the Brazilian Institute of Geography and Statistics (IBGE), we determined the predominant biomes in each Brazilian state. Using references to the locality of video production provided by the uploaders, we were able to identify the most commonly represented biomes in hunting videos in Brazil.

We compared the mean ratios of likes to dislikes assigned by viewers to videos of hunting events to determine the appreciation of internet users on the hunting videos. We also compared the mean ratios of posted comments for and against hunting to determine the opinion of commentators on sport hunting in Brazil. Finally, we compared the proportions of comments falling into each category according to our classification of comments. For all these comparisons, we applied repeated-measures ANOVAs. The tests were performed using Statistica 8.0 software, and the level of significance was $\mathrm{p}<0.05$.

\section{RESULTS}

Sharing and viewing sport hunting videos in Brazil

Of the 1600 videos analyzed, we identified 383 videos related to sport hunting activities in Brazil or practiced by Brazilians in other countries. These 383 videos were posted by 277 unique uploaders, generating an average of $1.38 \pm 1.45$ videos per uploader. Around $68 \%(\mathrm{n}=187)$ of the uploaders used their real names as their username and, based on their responses to the comments posted on YouTube ${ }^{\mathrm{TM}}$, it was clear that the hunters on the videos were in most cases the video uploaders. As of the date of our analysis, sport hunting videos had attracted a total of 15,397,753 views, 22,354 ratings, i.e., likes and dislikes, and 8417 comments generated by internet users on YouTube ${ }^{\mathrm{TM}}$. 
The number of videos posted on sport hunting increased exponentially over the years $(\mathrm{r}=0.96, \mathrm{p}<0.01)$, with the majority posted in the years $2013(\mathrm{n}=115,30.0 \%)$ and $2014(\mathrm{n}=104$, $27.2 \%$; Fig. 2). The main YouTube ${ }^{\mathrm{TM}}$ theme categories in which the uploaders classified their videos were People \& Blogs $(\mathrm{n}=$ $126,32.9 \%)$, Animals $(n=123,32.1 \%)$, Sports $(n=52,13.6 \%)$, and Entertainment $(n=37,9.7 \%)$. The remaining videos were classified in eleven additional categories $(n=45,11.7 \%)$.

Fig. 2. Exponential increase in the number of sport hunting videos posted on YouTube ${ }^{\mathrm{TM}}$ over the years.

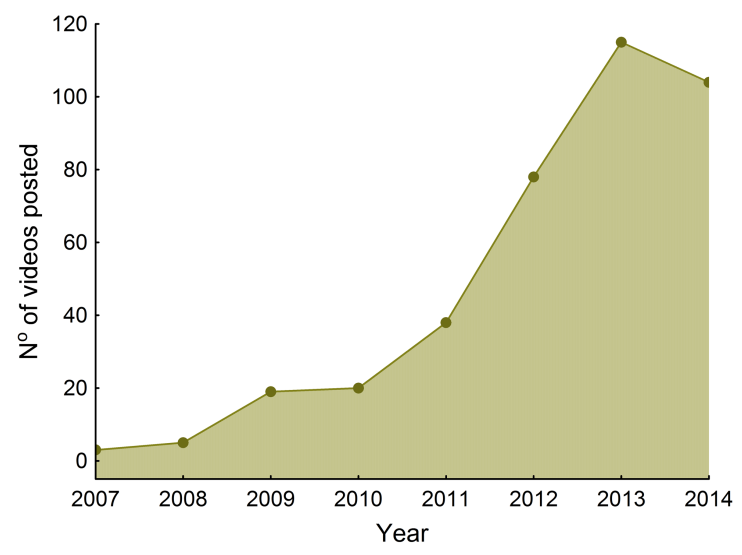

Regarding the type of videos found, 174 (45.5\%) reported successful hunting events, 94 (24.5\%) reported unsuccessful hunts, $88(23.0 \%)$ provided hunting instruction, and $27(7.0 \%)$ were advertisement videos. Most videos of hunting events were posted in July $(n=22,12.5 \%)$ and December $(n=23,13.0 \%$; Fig. 3$)$. Hunters showed their own faces on $101(38 \%)$ videos. Most of the videos of successful hunts showed wild animals being captured or killed $(n=169,97 \%)$. Of the five remaining videos, four showed the preparation of game meat for consumption and one reported a trade involving hunted wild animals. Of 124 hunting events in which it was possible to identify the weapon used, $88(70.9 \%)$ demonstrated the use of shotguns. Thirteen uploaders exposed the brand of the weapon used in the title or in the description of the video, and we could identify that 11 hunters used air pressure carbines and 2 hunters used firearms.

Fig. 3. Number of videos of hunting events posted on YouTube ${ }^{\mathrm{TM}}$ per month.

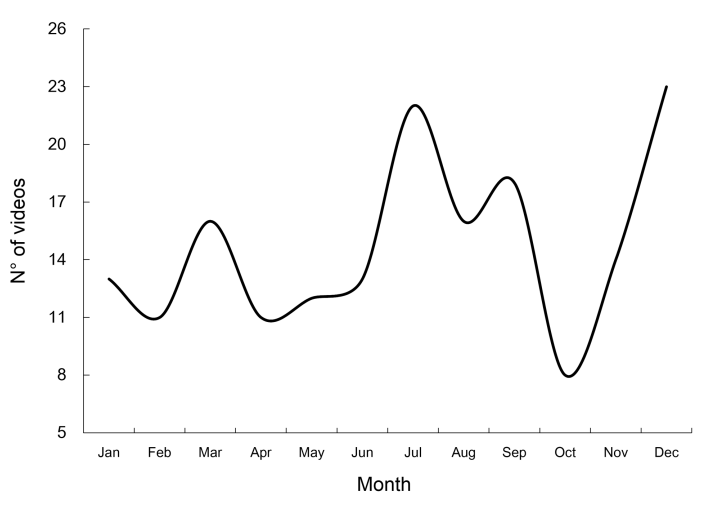

The most affected taxa and biomes

The target taxa with the highest frequency of posted videos were armadillos $(\mathrm{n}=44,24.9 \%)$ and the lowland paca (Cuniculus paca; $\mathrm{n}=38,21.5 \%$ ). For the lowland paca, the cumulative number of videos found throughout the results pages exhibits a linear growth trend (Table 2). In contrast, asymptotes are present in the accumulation curves of the remaining taxa (Fig. 4).

Table 2. Growth trend of the accumulation curves of hunting videos targeting the main hunted mammalian taxa in Brazil.

\begin{tabular}{|c|c|c|}
\hline Taxon & $\begin{array}{l}\text { Growth } \\
\text { trend }\end{array}$ & Statistics \\
\hline $\begin{array}{l}\text { Tapirs } \\
\text { Tapirus spp. }\end{array}$ & Logarithmic & $\mathrm{r}=0.89, \mathrm{p}<0.01$ \\
\hline $\begin{array}{l}\text { Deer } \\
\text { Family Cervidae }\end{array}$ & Logarithmic & $\mathrm{r}=0.82, \mathrm{p}<0.01$ \\
\hline $\begin{array}{l}\text { White-lipped peccary } \\
\text { Tayassu pecari }\end{array}$ & Logarithmic & $\mathrm{r}=0.90, \mathrm{p}<0.01$ \\
\hline $\begin{array}{l}\text { Collared peccary } \\
\text { Pecari tajacu }\end{array}$ & Logarithmic & $\mathrm{r}=0.95, \mathrm{p}<0.01$ \\
\hline $\begin{array}{l}\text { Capybara } \\
\text { Hydrochoerus hydrochaeris }\end{array}$ & Logarithmic & $\mathrm{r}=0.99, \mathrm{p}<0.01$ \\
\hline $\begin{array}{l}\text { Lowland paca } \\
\text { Cuniculus paca }\end{array}$ & Linear & $\mathrm{r}=0.99, \mathrm{p}<0.01, \mathrm{r}^{2}=0.94$ \\
\hline $\begin{array}{l}\text { Agoutis } \\
\text { Dasyprocta spp. }\end{array}$ & Logarithmic & $\mathrm{r}=0.94, \mathrm{p}<0.01$ \\
\hline $\begin{array}{l}\text { Armadillos } \\
\text { Family Dasypodidae }\end{array}$ & Logarithmic & $\mathrm{r}=0.99, \mathrm{p}<0.01$ \\
\hline
\end{tabular}

Fig. 4. Accumulation curves along the YouTube ${ }^{\mathrm{TM}}$ results pages of sport hunting videos of the eight mammalian taxa most often cited as hunting targets in Brazil. For scientific names of species, see Table 1 .

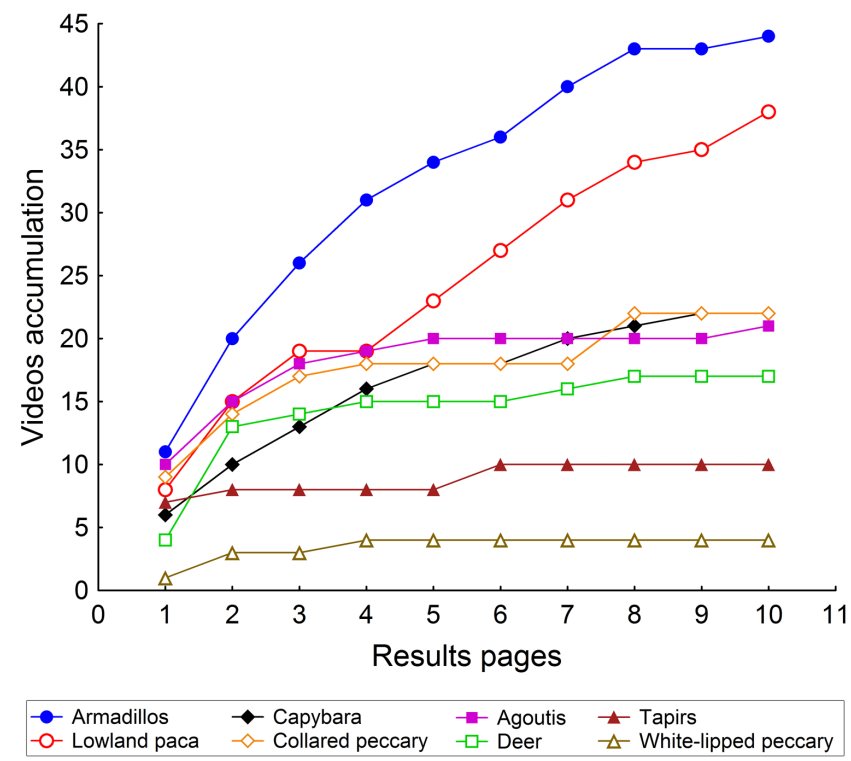

We found 36 additional taxa that appeared 92 times in 87 different videos (Table 3 ). In only seven videos these additional taxa were pursued in the same hunting event as the target taxa. Birds were 
Table 3. Number of records for each additional taxon (species not included in the search keys) detected on videos of hunting events on YouTube ${ }^{\mathrm{TM}}$.

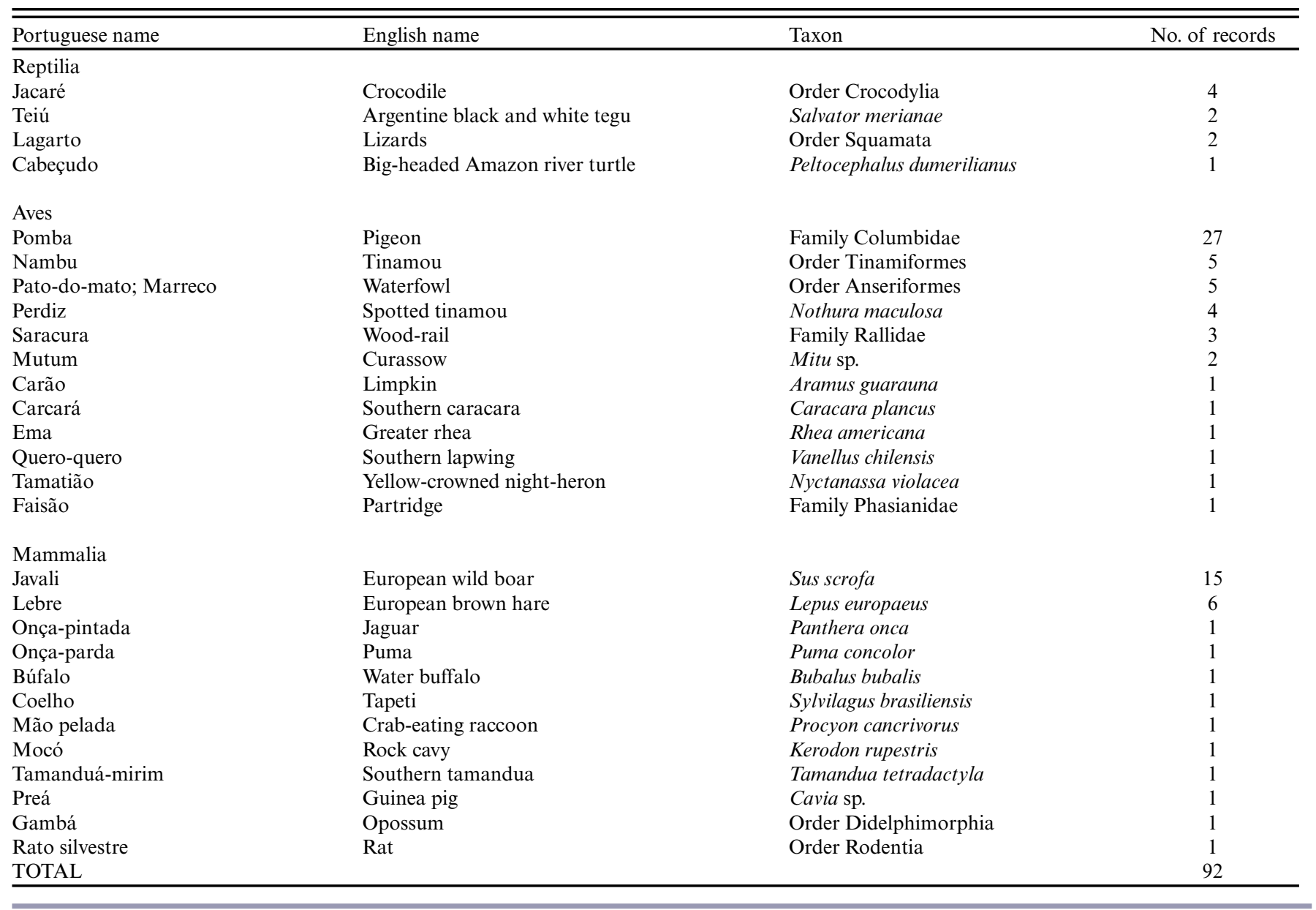

the group with the highest number of additional taxa appearances in the videos $(\mathrm{n}=52,56.5 \%)$, followed by mammals $(\mathrm{n}=31$, $33.7 \%)$, and reptiles $(\mathrm{n}=9,9.8 \%)$. Among the additional taxa, only the European wild boar $(\mathrm{n}=15)$, brown hare (Lepus europaeus; $\mathrm{n}=6$ ) and Spotted tinamou (Nothura maculosa; $\mathrm{n}=$ 4) are currently or have been legal to hunt; the first two are invasive alien species in Brazil.

Of all the identified videos, 105 included information on the location where they were produced. The most represented Brazilian biomes in the posted videos were the Cerrado (Brazilian savannah in southeastern and midwestern Brazil; $n=29,27.6 \%$ ) and the Caatinga (Brazilian tropical dry forest in northeastern Brazil; $\mathrm{n}=17,16.2 \%$; Fig. 5).

\section{Appreciation and opinion of internet users}

The average number of likes by viewers of hunting videos was higher than the average number of dislikes $\left(F_{1,148}=53.7, p<0.01\right)$. However, the appreciation of hunting videos varied by taxa, and for tapirs, the ratio of likes to dislikes was close to $1\left(\mathrm{~F}_{7,148}=2.2\right.$, $\mathrm{p}<0.05$; Fig. 6A). Following the pattern observed in the ratings, the average number of comments that were favorable toward sport hunting was significantly higher than the average number of comments against sport hunting $\left(\mathrm{F}_{1,80}=481.9, \mathrm{p}<0.01\right)$, regardless of taxon $\left(\mathrm{F}_{7,80}=1.3, \mathrm{p}>0.05\right.$; Fig. $\left.6 \mathrm{~B}\right)$.

Fig. 5. Distribution of the number of Brazilian sport hunting videos found by Brazilian state and biome or foreign country.

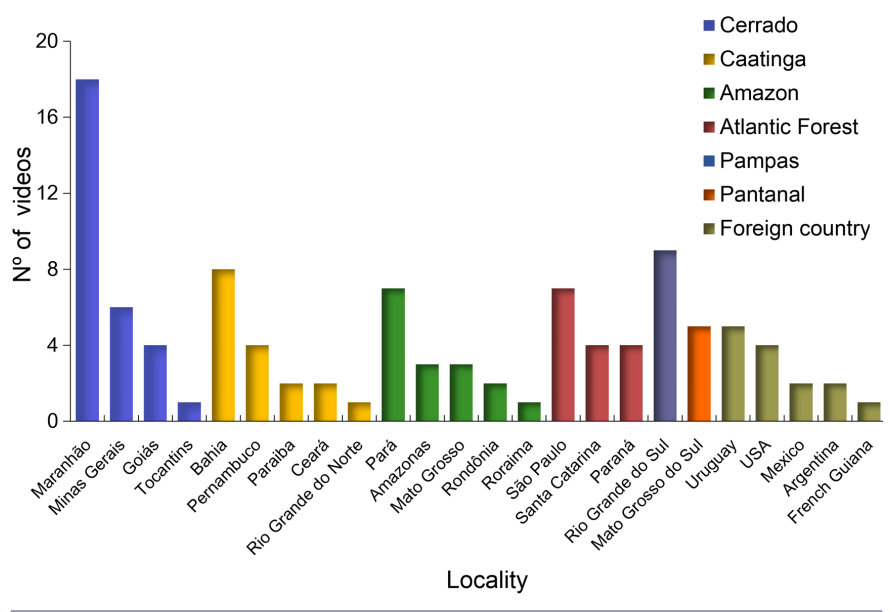


Fig. 6. Comparison of A: the means of proportions of likes and dislikes offered by internet users to hunting videos of the eight main mammalian taxa hunted in Brazil; and B: the means of proportions of comments for and against sport hunting in Brazil. For scientific names of species, see Table 1 .
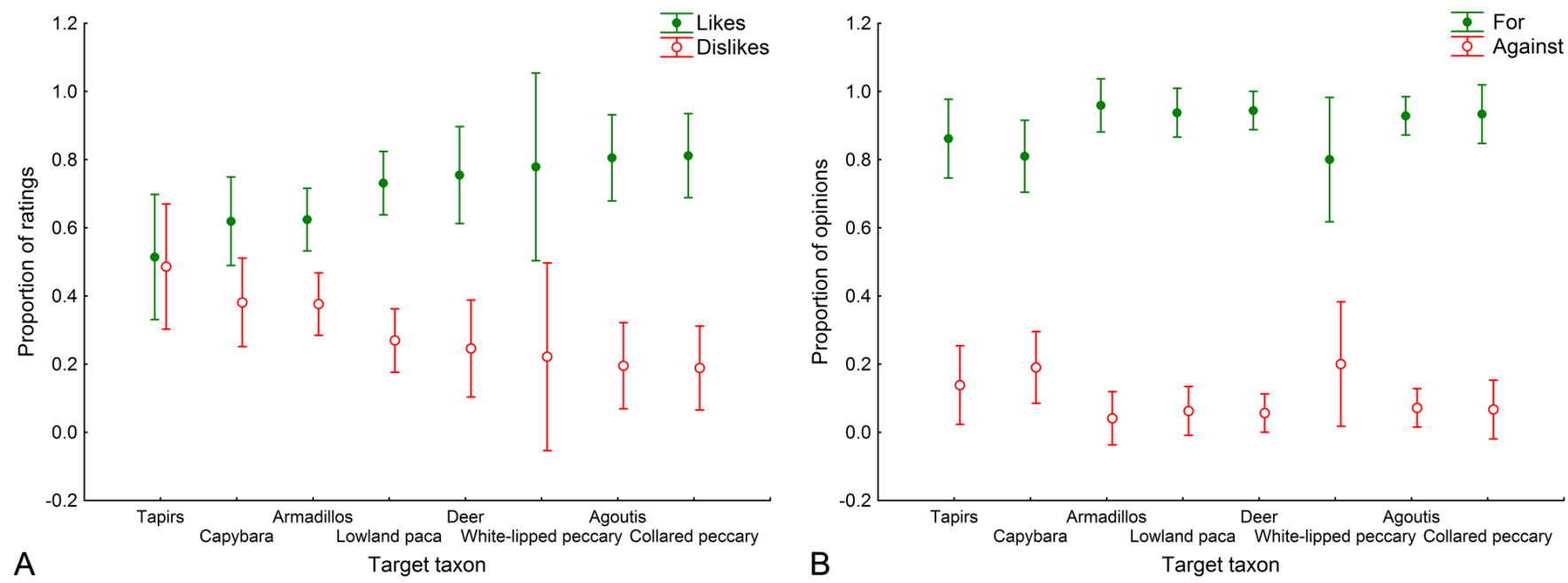

Most of the comments in favor of sport hunting consisted of questions and requests to the hunter and compliments and critiques of the hunting event $\left(\mathrm{F}_{5,440}=26.5, \mathrm{p}<0.01\right.$; Fig. 7). Only 87 comments opposed sport hunting activity. These comments consisted primarily of claims of cruel acts or immorality $(n=39$, $44.8 \%$ ), followed by claims of illegality $(n=26,29.9 \%)$, and discussions against hunting in Brazil $(\mathrm{n}=19,21.8 \%)$; only three cited Brazilian regulations or hunting laws (3.4\%).

Fig. 7. Comparison of the means of proportions of comments in favor of hunting activity. Q\&R = Questions for or requests to the uploader.

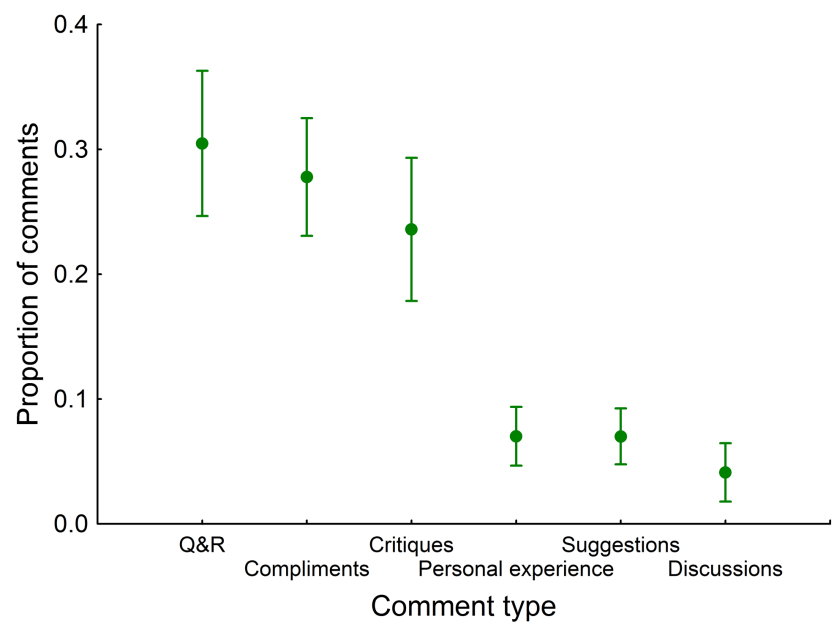

We identified the existence of several informal management rules that were applied and suggested by hunters or commentators regarding sport hunting. We classified the rules into five categories and provide original comments as illustrations (Fig. 8). The most frequently cited management rule referred to the welfare of hunted individuals.
Fig. 8. A diagram illustrating the five management rules possibly adopted by sport hunters in Brazil and some respective comments showing hunting attitudes based on these rules.

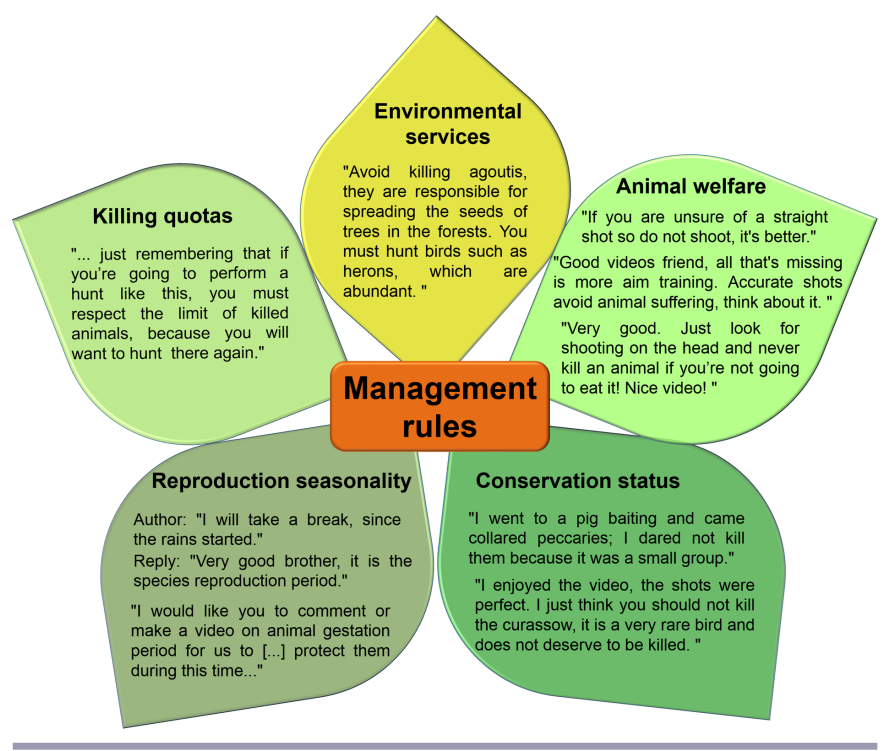

We also identified five main issues addressed in the discussions in favor of sport hunting in the country (Table 4). Most of these discussions suggest hunters' need to prove themselves as sportsmen and assert that all hunted animals are consumed. Furthermore, commentators and hunters discussed the regulation of sport hunting in Brazil, and there were intense arguments regarding Brazilian politics and environmental legislation.

\section{DISCUSSION}

The large number of videos on sport hunting posted on YouTube ${ }^{\mathrm{TM}}$ reveals the intensity of this activity in several regions of Brazil and the frequent use of communication media for the dissemination of 
Table 4. Main topics addressed by commentators in the discussions in favor of sport hunting in Brazil.

\begin{tabular}{|c|c|}
\hline Category & Comment \\
\hline $\begin{array}{l}\text { Arguments in favor of } \\
\text { sport hunting for } \\
\text { meat consumption }\end{array}$ & $\begin{array}{l}\text { "I personally find it absurd a hunter who hunts to eat having to hide his face because of terrible laws. I am a hunter and I } \\
\text { love to hunt, and I do it with respect for nature." } \\
\text { "I'm against killing for killing, but I am in favor of killing to eat." } \\
\text { "Do not mind the criticism. If you threw the meat away in this case it would be reprehensible, but since it is to eat, it is } \\
\text { acceptable." }\end{array}$ \\
\hline $\begin{array}{l}\text { Affirmation of the } \\
\text { identity and character } \\
\text { of the sport hunting }\end{array}$ & $\begin{array}{l}\text { "There is no pleasure in the suffering of an animal. If it was to see animals suffering, I would torture my dog or a pigeon on } \\
\text { the street. It's difficult to dialogue with the ignorant who do not know the meaning of sport hunting." } \\
\text { "I'm going to Para next month; I hunt deer there, because you know that our legislation does not allow our sport." }\end{array}$ \\
\hline $\begin{array}{l}\text { Legalization of sport } \\
\text { hunting }\end{array}$ & $\begin{array}{l}\text { "Brazil should copy some laws from the USA, such as the regulation of hunting seasons for some species." } \\
\text { "It is unfortunate that in our country hunting is prohibited, while in the United States it is legalized." }\end{array}$ \\
\hline $\begin{array}{l}\text { Comparison of the } \\
\text { impact of sport } \\
\text { hunting with that of } \\
\text { other human } \\
\text { activities }\end{array}$ & $\begin{array}{l}\text { "There are people against the killing of animals, while companies and large multinationals are clearing forests for their } \\
\text { facilities and killing many animals. The law protects them." }\end{array}$ \\
\hline $\begin{array}{l}\text { Conflicts with } \\
\text { environmentalists }\end{array}$ & $\begin{array}{l}\text { "The environmentalists fight for the preservation of the forests, but they have wooden furniture in their homes. Criminal is } \\
\text { the person who cuts trees and sells the wood." } \\
\text { "These environmentalists do not farm because if they farmed they would know the magnitude of the damage that this } \\
\text { animal causes." } \\
\text { "Environmentalists fight against hunting but they buy meat in the market (they must think that the meat is born there). } \\
\text { Please, watch the videos of slaughterhouses and see the meat you eat." } \\
\text { "I love hunting, and it's a pity that in the country where I live I need to be clandestine and judged by "office } \\
\text { environmentalists"." }\end{array}$ \\
\hline
\end{tabular}

ideas related to this practice. The Brazilian federal environmental agency claims that its lack of attention to sport hunting is based on the lack of social relevance of this activity (Nassaro 2011). In contrast to the government's perception, we identified a large number of sport hunters in the country, including the uploaders of the videos and many commentators who do not post videos but share information about their hunts, and also numerous internet users who are interested in the subject. The number of views observed in this study corresponds to an estimated $7.4 \%$ of the Brazilian population. In addition, despite the fact that sport hunting is illegal in most cases, the interest in sharing sport hunting activities on YouTube ${ }^{\mathrm{TM}}$ seems to be increasing every year. The increasing number of postings could also be due to the increasing internet accessibility by Brazilian urban population (Brasil 2014), but regardless of the cause of this increase, the number of sport hunters acting illegally in Brazil is much higher than previously believed.

The posting dates of hunting videos suggest that sport hunting in Brazil is possibly seasonal and concentrated during the main Brazilian vacation periods (July and December). These results indicate that most of the hunters are urban residents who take advantage of these periods to travel and access rural areas where game species are available, as also detected by Alves et al. (2009) for sport hunters in northeastern Brazil and by Ojasti (1996) for sport hunters in countries of Latin America.

Parry et al. (2014) found that hunting by urban dwellers in the Brazilian Amazon is closely related to poverty because wealthier urban residents usually choose to buy game meat rather than hunt. Van Vliet et al. (2015) also detected that urban hunters in the
Amazonian tri-frontier sell the meat obtained to complement their household income. In contrast to these authors, we detected that Brazilian sport hunters are not guided by subsistence or income needs, but by the thrill of chasing target species and consuming game meat. The sport hunters on YouTube ${ }^{\mathrm{TM}}$ spent large sums of money to buy the equipment used during their hunts. The cost of the air pressure carbines we identified on videos ranged from US\$350.00 to US\$2000.00 (1 US Dollar $=2.15$ Brazilian Real), and the minimum value is close to the minimum Brazilian wage (US\$366.50). These hunting expenditures show that the sector of the Brazilian society involved in sport hunting is not the rural poor who normally need to hunt to survive. In agreement with our results, Alves et al. (2012) also detected that only wealthier urban hunters in the Brazilian semiarid region consider the activity as a sport.

The main target species reported on videos are the same as those affected by subsistence hunting and trade by rural populations in Brazil (e.g., Valsecchi and Amaral 2009, Souza and Alves 2014). The estimated accumulation curves revealed that the number of hunting videos in which armadillos and especially pacas are targeted is likely to be well above the number we analyzed, suggesting strong hunting pressure on these taxa. Dantas-Aguiar et al. (2011) reported that armadillos represent $70 \%$ of animals hunted in northeastern Brazil. Barboza et al. (2011) also stated that armadillos are hunted for sport in this Brazilian region. In addition, the lowland paca, even if not globally threatened, has a worrying conservation status on nearly every state list of endangered species in Brazil and is severely affected by hunting even in remote areas (e.g., Valsecchi et al. 2014, El Bizri et al. 
2015). Other species that are also targets of sport hunting in the videos are already threatened according to the International Union for Conservation of Nature, such as the tapir (Tapirus terrestris), white-lipped peccary (Tayassu peccary), and threebanded armadillo (Tricinctus tolypeutes). This fact underscores the need to estimate the possible impacts of sport hunting on Brazilian wildlife.

Large mammal species such as tapirs and the white-lipped peccary may appear in fewer videos because, in the most populous regions of the country, the remaining preserved remnants are not large enough to support populations of these species (Morcatty et al. 2013). The proportion of each target taxon that we found in videos is very similar to the proportion found by Sampaio (2011) in interviews with sport hunters in the state of Rio de Janeiro, indicating that YouTube ${ }^{\mathrm{TM}}$ videos may be reflecting the real rates with which sport hunters harvest each taxon in Brazil. The frequency with which we found videos of hunting events of exclusively additional taxa also suggests that other species are common targets of sport hunting and must be considered in conservation research and policies.

Sport hunting was recorded in all Brazilian biomes, but we found the highest concentration of videos in the Cerrado, one of the most threatened biomes in Brazil. Along with the Atlantic Forest, the Cerrado is considered a hotspot of biodiversity (Myers et al. 2000), and because these biomes suffer intensely from habitat fragmentation, the impacts of hunting are amplified in these environments (Peres 2001). The Caatinga appeared frequently in the videos and is a biome that has suffered great degradation (Leal et al. 2005). Alves et al. (2009) also detected a high number of sport hunters acting in the Caatinga biome. It is therefore urgent to invest in research on sport hunting in Brazil, especially in regions where this activity is most likely to be occurring.

The classification by the uploaders of most of the videos as belonging to the People \& Blogs category supports the hypothesis that YouTube ${ }^{\mathrm{TM}}$ is a forum for sport hunters to socialize. The comment space is primarily used to share experiences, and these exchanges generate a large number of questions and requests that are often met. Despite the fact that hunting is not regulated, a sense of identity as practitioners of a sport has been formed by the group of hunters. This identity is reflected in many videos categorized as Sports and Entertainment and discussions generated by the comments that defined the activity as a sport.

A drawback to the use of YouTube ${ }^{\mathrm{TM}}$ for hunting studies is related to internet access, which is not uniform in the Brazilian population (Brasil 2014). However, YouTube ${ }^{\mathrm{TM}}$ proved to be an effective tool for collecting information on a neglected subject in Brazil and can be used to monitor the sport hunting activity throughout the country. The authors, viewers, and commentators expose themselves on the website to demonstrate an act that is criminalized by law. Van Vliet et al. (2015) showed that urban hunters who trade bushmeat in the Brazilian Amazon normally fear surveillance. Most hunters in YouTube ${ }^{\mathrm{TM}}$ exhibited their personal names and many of them exposed their faces on hunting videos, showing that sport hunters adopt few or no strategies to avoid surveillance because they probably recognize that surveillance actions are ineffectual in Brazil, especially when the hunting does not involve the trade of the meat. In addition, sport hunters seem to understand that the activity is illegal and often justify themselves by claiming that the meat will be consumed, likely alluding erroneously to the decriminalization of hunting to satisfy the need for food, as outlined in Law No. 9,605/98. On the other hand, hunters showed concern about being inspected for using firearms because most of them used air pressure carbines during their hunts and one does not need permits to purchase these types of weapons in Brazil (Law No. 10,826/2003). Given that even medium-sized mammals such as pacas and armadillos can be felled by shots of air pressure carbines, the selling of these weapons should also be controlled by Brazilian federal agencies.

Videos posted on YouTube ${ }^{\mathrm{TM}}$ are the responsibility of the authors, but the website has an internal policy for the user community. This policy states that any act of harassment or violence against people is cause for the user and video to be banned. However, the website does not mention persecution or violence toward animals, nor does it address illegal acts. Brazilian Law No. 2,848/40 states that public communication of a criminal act is liable to punishment. Thus, it is crucial to consider screening methods for Brazilian videos of sport hunting on YouTube ${ }^{\mathrm{TM}}$, differentiating videos of illegal sport hunting from those portraying regulated hunting activity in the country.

However, to simply control the availability of videos would not take the necessary effect and can mask the coverage and impact of the sport hunting in Brazil. In addition to this measure, the surveillance of sport hunting activity should be intensified, especially in strictly protected reserves and forest remnants near urban centers (Chiarello 2000).

With regard to sport hunters who hunt for game meat for consumption, a potential solution might be found in the increasing incentives surrounding the rearing of wild species for sale in Brazil (Nogueira and Nogueira-Filho 2011). However, we realize that the greatest motivation for sport hunting in the country seems to arise from an appreciation for the pursuit and killing of game animals. In this context, the authorization and stimulus of hunting programs targeting invasive alien species may be a viable solution. In the Brazilian Pantanal, Desbiez et al. (2011) reported that locals prefer to shoot European wild boar because it is illegal to hunt native species. In addition, because of such adherence to regulations regarding the sport hunting of native wild animals, permission to hunt native species may be considered as well. Hunting in Brazil does not seem to be exclusively related to the killing of rare animals or those with valuable attributes (Sampaio 2011). This fact favors a management policy for species with higher reproductive rates, especially natural prey, and minimizes the impacts of strong sexual selection and the preference for predators, as found in trophy hunting (Loveridge et al. 2006).

Experiences in Brazil suggest that it is possible to reconcile local sport hunting with conservation. The sport hunting of native bird species in the state of Rio Grande do Sul, for example, was successfully permitted for five years and the populations of the target species remained stable with the defined harvest rates (Efe et al. 2005). Furthermore, Efe et al. (2005) observed that Rio Grande do Sul exhibited greater richness and larger populations of waterfowl species than the states where sport hunting remained prohibited because many traditional hunting areas were spared from habitat conversion. 
Loveridge et al. (2006) argue that hunters can be effective stakeholders in the protection of habitats. For a hunting regulation to be well structured, it must create rules and assure compliance by the people involved. In Namibia, the involvement of local stakeholders in the development of hunting policies led to higher conservation effectiveness. In this case, $10 \%$ of the national area was turned into Communal Conservancies Units, where regulated sport hunting was fundamental to recover populations of nearly extinct game species (Nelson et al. 2005, Boudreaux and Nelson 2011). The sport hunters on YouTube ${ }^{\mathrm{TM}}$ also have hunting rules that, although informal, are assumed by various group members, such as the interest in protecting hunting areas and the respect for breeding seasons. If these rules meet the biological and ecological needs for maintaining and increasing populations of prized game species, compliance is favored.

Regardless of the attitude adopted by the Brazilian government with respect to sport hunting in Brazil, public education and awareness campaigns are clearly an important measure, and it is urgent they be undertaken (Melo et al. 2014). Furthermore, the lack of scientific investment in sport hunting studies in the country contributes to the lack of political progress regarding this activity. Based on YouTube ${ }^{\mathrm{TM}}$ hunting videos, we were able to demonstrate the magnitude of sport hunting in Brazil and support the necessity of establishing measures to solve the impacts generated by this activity, showing that social web sites have great potential to be used to monitor and provide information on hunting throughout the world (e.g., Miyazaki et al. 2014) and to heighten public awareness, especially because of their influence on people's attitudes (e.g., Nekaris et al. 2013).

The sport hunting in Brazil represents a conservation opportunity in several contexts, but it may deplete game species populations if not properly regulated and managed. Thus, sport hunting in Brazil should be included in efforts to solve the global hunting impacts.

Responses to this article can be read online at: http://www.ecologyandsociety.org/issues/responses. php/7882

\section{Acknowledgments:}

We thank the National Council for Scientific and Technological Development $(\mathrm{CNPq})$ and the Ministry of Science, Technology and Innovation (MCTI) for their financial support. We also thank $A$. B. Rodrigues for his support in data collection.

\section{LITERATURE CITED}

Alves, R. R. N. 2009. Fauna used in popular medicine in Northeast Brazil. Journal of Ethnobiology and Ethnomedicine 5:1. http://dx.doi.org/10.1186/1746-4269-5-1

Alves, R. R. N., M. B. R. Gonçalves, and W. L. S. Vieira. 2012. Caça, uso e conservação de vertebrados no semiárido Brasileiro. Tropical Conservation Science. 5(3):394-416.

Alves, R. R. N, L. E. T. Mendonça, M. V. A. Confessor, W. L. S. Vieira, and L. C. S. Lopez. 2009. Hunting strategies used in the semi-arid region of northeastern Brazil. Journal of Ethnobiology and Ethnomedicine 5(12):1-50. http://dx.doi.org/10.1186/1746-4269-5-12

Alves, R. R. N., and W. M. S. Souto. 2011. Ethnozoology in Brazil: current status and perspectives. Journal of Ethnobiology and Ethnomedicine 7:22. http://dx.doi.org/10.1186/1746-4269-7-22

Barboza, R. R. D., J. S. Mourão, W. M. S. Souto, and R. R. N. Alves. 2011. Knowledge and strategies of armadillo (Dasypus novemcinctus L. 1758 and Euphractus sexcinctus L. 1758) hunters in the Sertão Paraibano, Paraíba state, NE Brazil. Bioremediation, Biodiversity and Bioavailability 5:1-7.

Boudreaux, K., and F. Nelson. 2011. Community conservation in Namibia: empowering the poor with property rights. Economic Affairs 31(2):17-24. http://dx.doi.org/10.1111/j.1468-0270.2011.02096. $\underline{\mathrm{X}}$

Brasil. 2014. Pesquisa brasileira de mídia 2015: hábitos de consumo de mídia pela população brasileira. Secom, Brasília, Brazil.

Brasil. 2015. Portal Brasileiro de Dados Abertos - Plataforma de Gestão de Indicadores (PGI). Government of Brazil, Brasília, Brazil. [online] URL: https://i3gov.planejamento.gov.br/dadosgov/? $\mathrm{p}=$ catalogo

Chiarello, A. G. 2000. Influência da caça ilegal sobre mamíferos e aves das matas de tabuleiro do norte do estado do Espírito Santo. Boletim do Museu de Biologia Professor Mello Leitão (Nova Série) 11/12:229-247.

Cullen, L., R. E. Bodmer, and C. Valladares-Padua. 2001. Ecological consequences of hunting in Atlantic forest patches, São Paulo, Brazil. Oryx 35(2):137-144.

Dantas-Aguiar, P. R., R. M. Barreto, D. Santos-Fita, and E. B. Santos. 2011. Hunting activities and wild fauna use: a profile of Queixo D'antas community, Campo Formoso, Bahia, Brazil. Bioremediation, Biodiversity and Bioavailability 5(1):34-43.

Deák, C., and S. Schiffer. 1999. O processo de urbanização no Brasil. Editora Universidade de São Paulo, São Paulo, São Paulo, Brazil.

Deberdt, A. J., and S. B. Scherer. 2007. O javali asselvajado: ocorrência e manejo da espécie no Brasil. Natureza \& Conservação 5(2):23-30.

Desbiez, A. L. J., A. Keuroghlian, U. Piovezan, and R. E. Bodmer. 2011. Invasive species and bushmeat hunting contributing to wildlife conservation: the case of feral pigs in a Neotropical wetland. Oryx 45(1):78-83. http://dx.doi.org/10.1017/s0030605310001304

Efe, M. A., L. V. Mohr, C. Martins-Ferreira, and J. L. X. Nascimento. 2005. Análise das fichas individuais de controle no processo de caça de anatídeos no Rio Grande do Sul. Ornithologia 1(1):7-12.

El Bizri, H., L. W. Araújo, W. Araújo, L. Maranhão, and J. Valsecchi. 2015. Turning the game around for conservation: using traditional hunting knowledge to improve the capture efficiency of Amazon lowland paca. Wildlife Biology. http://dx.doi. org/10.2981/wlb.00127

Fa, J. E., and J. E. Garcia Yuste. 2001. Commercial bushmeat hunting in the Monte Mitra forests, Equatorial Guinea: extent and impact. Animal Biodiversity and Conservation 24(1):31-52. 
Fa, J. E., C. A. Peres, and J. Meeuwig. 2002. Bushmeat exploitation in tropical forests: an intercontinental comparison. Conservation Biology 16(1):232-237. http://dx.doi.org/10.1046/j.1523-1739.2002.00275. $\underline{x}$

Fernandes-Ferreira, H., and R. R. N. Alves. 2014. Legislação e mídia envolvendo a caça de animais silvestres no Brasil: uma perspectiva histórica e socioambiental. Revista Gaia Scientia 8 (1):1-7.

Gandiwa, E., I. M. A. Heitkönig, A. M. Lokhorst, H. H. T. Prins, and C. Leeuwis. 2013. CAMPFIRE and human-wildlife conflicts in local communities bordering northern Gonarezhou National Park, Zimbabwe. Ecology and Society 18(4): 7. http://dx.doi. org/10.5751/es-05817-180407

Guadagnin, D. L., L. F. C. Perello, and J. O. Menegheti. 2007. A situação atual da caça de lazer e manejo de áreas úmidas no Rio Grande do Sul [Current situation of leisure hunting and wetland management in Rio Grande do Sul State, South Brazil]. Neotropical Biology and Conservation 2:63-70.

Henderson, D. W., R. J. Warren, D. H. Newman, J. M. Bowker, J. S. Cromwell, and J. J. Jackson. 2000. Human perceptions before and after a 50\% reduction in an urban deer herd's density. Wildlife Society Bulletin 28(4):911-918.

IBGE (Brazilian Institute of Geography and Statistics). 2011. Censo demográfico 2010: Características da população e dos domicílios. Resultados do universo. Ministério do Orçamento, Planejamento e Gestão, Rio de Janeiro, Brasil.

Jackson, J. J. 1996. An international perspective on hunting. Pages 7-11 in N. Leader-Williams, J. A. Kayera, and G. L. Overton, editors. Tourist hunting in Tanzania. Occasional Publication 14. International Union for the Conservation of Nature and Natural Resources, Cambridge, UK.

Leader-Williams, N., and J. M. Hutton. 2005. Does extractive use provide opportunities to offset conflicts between people and wildlife? Pages 140-161 in R. Woodroffe, S. J. Thirgood, and A. Rabinowitz, editors. People and wildlife: conflict or coexistence? Cambridge University Press, Cambridge, UK.

Leal, I. R., J. M. C. Silva, M. Tabarelli, and T. E. Lacher Jr. 2005. Mudando o curso da conservação da biodiversidade na Caatinga do Nordeste do Brasil. Megadiversidade 1(1):139-146.

Lindsey, P. A., L. G. Frank, R. Alexander, A. Mathieson, and S. S. Romanach. 2007a. Trophy hunting and conservation in Africa: problems and one potential solution. Conservation Biology 21 (3):880-883. http://dx.doi.org/10.1111/j.1523-1739.2006.00594.x

Lindsey, P. A., P. A. Roulet, and S. S. Romañach. 2007b. Economic and conservation significance of trophy hunting industry in subSaharan Africa. Biological Conservation 134:455-469. http://dx. doi.org/10.1016/j.biocon.2006.09.005

Loveridge, A. K., J. C. Reynolds, and E. J. Milner-Gulland. 2006. Does sport hunting benefit conservation? Pages 224-239 in D. Macdonald, and K. Service, editors. Key topics in conservation biology. Blackwell, Oxford, UK.

Mayor, P., D. A. Guimarães, and C. López. 2013. Functional morphology of the genital organs in the wild paca (Cuniculus paca) female. Animal Reproduction Science 140:206-215. http:// dx.doi.org/10.1016/j.anireprosci.2013.06.010
Melo, R. S., O. C. Silva, A. Souto, R. R. N. Alves, and N. Schiel. 2014. The role of mammals in local communities living in conservation areas in the Northeast of Brazil: an ethnozoological approach. Tropical Conservation Science 7(3):423-439.

Milner-Gulland, E. J., E. L. Bennett, and the SCB 2002 Annual Meeting Wild Meat Group. 2003. Wild meat: the bigger picture. Trends in Ecology and Evolution 18:351-357. http://dx.doi. org/10.1016/S0169-5347(03)00123-X

Miyazaki, Y., A. Murase, M. Shiina, K. Naoe, R. Nakashiro, J. Honda, J. Yamaide, and H. Senou. 2014. Biological monitoring by citizens using Web-based photographic databases of fishes. Biodiversity and Conservation 23(9):2383-2391. http://dx.doi. org/10.1007/s10531-014-0724-4

Morcatty, T. Q., H. R. El Bizri, H. C. S. Carneiro, R. L. Biasizzo, C. R. O. Alméri, E. S. Silva, F. H. G. Rodrigues, and J. E. C. Figueira. 2013. Habitat loss and mammalian extinction patterns: are the reserves in the Quadrilátero Ferrifero, southeastern Brazil, effective in conserving mammals? Ecological Research 28 (6):935-947. http://dx.doi.org/10.1007/s11284-013-1076-3

Morcatty, T. Q., and J. Valsecchi. 2015. Social, biological, and environmental drivers of the hunting and trade of the endangered yellow-footed tortoise in the Amazon. Ecology and Society 20(3): 3. http://dx.doi.org/10.5751/es-07701-200303

Mutandwa, E., and C. T. Gadzirayi. 2007. Impact of communitybased approaches to wildlife management: case study of the CAMPFIRE programme in Zimbabwe. International Journal of Sustainable Development \& World Ecology 14:336-344. http://dx. doi.org/10.1080/13504500709469734

Myers N., R. A. Mittermeier, C. G. Mittermeier, G. A. B. da Fonseca, and J. Kent. 2000. Biodiversity hotspots for conservation priorities. Nature 403:853-858. http://dx.doi.org/10.1038/35002501

Nasi, R., D. Brown, D. Wilkie, E. Bennett, C. Tutin, G. van Tol, and T. Christophersen. 2008. Conservation and use of wildlifebased resources: the bushmeat crisis. CBD Technical Series Number 33. Secretariat of the Convention on Biological Diversity, Montréal, Québec, Canada, and Center for International Forestry Research, Bogor, Indonesia. [online] URL: http://www.cbd.int/doc/publications/cbd-ts-33-en.pdf

Nasi, R., A. Taber, and N. van Vliet. 2011. Empty forests, empty stomachs? Bushmeat and livelihoods in the Congo and Amazon Basins. International Forestry Review 13(3):355-368. http://dx.doi. org/10.1505/146554811798293872

Nassaro, A. L. F. 2011. A evolução do aparato normativo de proteção à fauna diante dos atos de caça no Brasil. Tempos Históricos 15(2):15-44.

Nekaris, K. A. I., N. Campbell, T. G. Coggins, E. J. Rode, and V. Nijman. 2013. Tickled to death: analysing public perceptions of 'cute' videos of threatened species (slow lorises-Nycticebus spp.) on Web 2.0 sites. PLoS ONE 8:e69215. http://dx.doi.org/10.1371/ journal.pone.0069215

Nelson, F., J. Mike, and A. Williams. 2005. Hunting, sustainability, and property rights in East and Southern Africa. African Indaba 3(4):8-9. 
Nogueira, S. S. C., and S. L. G Nogueira-Filho. 2011. Wildlife farming: an alternative to unsustainable hunting and deforestation in Neotropical forests? Biodiversity and Conservation 20:1385-1397. http://dx.doi.org/10.1007/s10531-011-0047-7

Ojasti, J. 1996. Wildlife utilization in Latin America: current situation and prospects for sustainable management. Food and Agriculture Organization, Rome, Italy.

Parry, L., J. Barlow, and H. Pereira. 2014. Wildlife harvest and consumption in Amazonia's urbanized wilderness. Conservation Letters 7:565-574. http://dx.doi.org/10.1111/conl.12151

Peres, C. A. 2000. Effects of subsistence hunting on vertebrate community structure in Amazonian forests. Conservation Biology 14(1):240-253. http://dx.doi.org/10.1046/j.1523-1739.2000.98485. $\underline{\mathrm{x}}$

Peres, C. A. 2001. Synergistic effects of subsistence hunting and habitat fragmentation on Amazonian forest vertebrates. Conservation Biology 15:1490-1505. http://dx.doi.org/10.1046/ j.1523-1739.2001.01089.x

Pérez, E. M., and J. Ojasti. 1996. La utilización de la fauna silvestre en la América tropical y recomendaciones para su manejo sustentable en las sabanas. Ecotropicos 9(2):71-82.

Pinheiro, G. C. 2014. A regulamentação da caça no Brasil. Revista de Direito Público da Procuradoria-Geral do Município de Londrina 3(2):96-116.

Proulx, R., P. Massicotte, and M. Pépino. 2014. Googling trends in conservation biology. Conservation Biology 28(1):44-51. http:// dx.doi.org/10.1111/cobi.12131

Redford, K. H. 1992. The empty forest. BioScience 42(6):412-422. http://dx.doi.org/10.2307/1311860

Sampaio, D. R. 2011. A caça illegal de animais silvestres na Mata Atlântica, Baixada litorânea do estado do Rio de Janeiro, Brasil: Eficiência de proteção de Reservas Biológicas e triangulação do perfil da caça. Dissertation. Universidade Estadual do Norte Fluminense Darcy Ribeiro, Campos dos Goytacazes, Rio de Janeiro, Brazil.

Souza, J. B., and R. R. N. Alves. 2014. Hunting and wildlife use in an Atlantic forest remnant of northeastern Brazil. Tropical Conservation Science 7(1):145-160.

Valsecchi, J., and P. V. Amaral. 2009. Perfil da caça e dos caçadores na Reserva de Desenvolvimento Sustentável Amanã, Amazonas - Brasil. Uakari 5(2):33-48.

Valsecchi, J., H. R. El Bizri, and J. E. C. Figueira. 2014. Subsistence hunting of Cuniculus paca in the middle of the Solimões River, Amazonas, Brazil. Brazilian Journal of Biology 74(3):560-568. http://dx.doi.org/10.1590/bjb.2014.0098

van Vliet, N., D. Cruz, M. Quiceno-Mesa, L. Neves de Aquino, J. Moreno, R. Rairon, and J. Fa. 2015. Ride, shoot, and call: wildlife use among contemporary urban hunters in Três Fronteiras, Brazilian Amazon. Ecology and Society 20(3): 8. http://dx.doi.org/10.5751/es-07506-200308

van Vliet, N., and R. Nasi. 2008. Hunting for livelihood in northeast Gabon: patterns, evolution, and sustainability. Ecology and Society 13(2): 33. van Vliet, N., M. P. Quiceno-Mesa, D. Cruz-Antia, L. J. N. Aquino, J. Moreno, and R. Nasi. 2014. The uncovered volumes of bushmeat commercialized in the Amazonian trifrontier between Colombia, Peru \& Brazil. Ethnobiology and Conservation 3:1-7.

Weber, M., G. García-Marmolejo, and R. Reyna-Hurtado. 2006. The tragedy of the commons: wildlife management units in southeastern Mexico. Wildlife Society Bulletin 34(5):1480-1488. http://dx.doi.org/10.2193/0091-7648(2006)34[1480:ttotcw]2.0.co;2

Yasuda, A. 2012. Is sport hunting a breakthrough wildlife conservation strategy for Africa? A case study of northern Cameroon. Field Actions Science Reports 6. 
Appendix 1. Literature consulted in this study to define the eight mammalian taxa most often cited as hunting targets in Brazil.

1. Almeida, G. S., P. O. Sousa, A. M. Souza, C. R. Souza, and K. A. Oliveira. 2012. Percepção das populações do interior e do entorno do Parque Nacional Serra do Divisor - Acre sobre a caça cinegética e seus efeitos sobre a abundância dos recursos faunísticos. Enciclopédia Biosfera 8(15):1902-1912.

2. Alves, R. R. N., M. B. R. Gonçalves, and W. L. S Vieira. 2012. Caça, uso e conservação de vertebrados no semiárido Brasileiro. Tropical Conservation Science 5(3):394-416.

3. Alves, R. R. N., L. E. T. Mendonça, M. V. A. Confessor, W. L. S. Vieira, and L. C. S. Lopez. 2009. Hunting strategies used in the semi-arid region of northeastern Brazil. Journal of Ethnobiology and Ethnomedicine 5:1-50.

4. Alves, R. R. N., R. O. Sousa Neta, D. M. B. M. Trovão, J. E. L. Barbosa, A. T. Barros, and T. L. P. Dias. 2012. Traditional uses of medicinal animals in the semi-arid region of northeastern Brazil. Journal of Ethnobiology and Ethnomedicine 8:41.

5. Andriguetto-Filho, J. M., A. C. Krüger and M. B. R. Lange. 1998. Caça, Biodiversidade e Gestão Ambiental na Área de Proteção Ambiental de Guaraqueçaba, Paraná, Brasil. Biotemas 11(2):133-156.

6. Araújo, R. M., M. B. Souza and C. R. Ruiz-Miranda. 2008. Densidade e tamanho populacional de mamíferos cinegéticos em duas Unidades de Conservação do Estado do Rio de Janeiro, Brasil. Iheringia Série Zoológica 98(3):391-396.

7. Ayres, J. M., and C. Ayres. 1979. Aspectos da caça no alto rio Aripuanã. Acta Amazonica 9(2): 287-298.

8. Baía-Júnior, P. C. 2006. Caracterização do uso comercial e de subsistência da fauna silvestre no município de Abaetetuba, PA. Dissertation. Universidade Federal do Pará, Centro de Ciências Agrárias, Belém, Pará, Brasil.

9. Baía-Júnior, P. C., D. A. Guimarães and Y. Le Pendu. 2010. Non-legalized commerce in game meat in the Brazilian Amazon: a case study. Revista de Biología Tropical 58(3):1079-1088.

10. Barbosa, A., D. S. C. Oliveira and C. R. M. Oliveira. 2014. Uso tradicional da fauna silvestre do município de Lapão - Bahia. Enciclopédia Biosfera 10(18):118.

11. Barbosa, J. A. A. and J. O. Aguiar. 2012. Utilização místico-tradicional da fauna no semiárido paraibano. Polêmica 11(4):642-649.

12. Barbosa, J. A. A., V. A. Nobrega and R. R. N. Alves. 2011. Hunting practices in the semiarid region of Brazil. Indian Journal of Traditional Knowledge 10(3):486-490.

13. Bastos, L. F., V. L. F. Luz and V. L. Souza 2008. Apreensão de espécimes da fauna silvestre em Goiás: situação e destinação. Revista Biologia Neotropical 5(2):51-63.

14. Bernardo, C.S. 2004. Abundância, densidade e tamanho populacional de aves e mamíferos cinegéticos no Parque Estadual Ilha do Cardoso, SP, Brasil. Dissertation. Escola Superior de Agricultura, Universidade de São Paulo, Piracicaba, São Paulo, Brasil.

15. Bisaggio, E. L., S. L. Alves and S. T. Brasil. 2008. Mamíferos como caça de subsistência em duas Reservas Extrativistas na Amazônia Ocidental. In: Anais do IV Congresso Brasileiro de Mastozoologia. São Lourenço, Minas Gerais, Brasil.

16. Braga, F. G. and Y. S. Kuniyoshi. 2010. Estimativas de parâmetros populacionais e demográficos de Ozotoceros bezoarticus (Artiodactyla, Cervidae) em Piraí do Sul, Paraná, sul do Brasil. Iheringia Série Zoológica 100:105-110. 
17. Calouro, A. M. and J. S. Marinho-Filho. 2005. A caça e a pesca de subsistência entre seringueiros ribeirinhos e não ribeirinhos da Floresta Estadual do Antimary (AC). Pages 109-135 In: Drumond, P. M., editor. Fauna do Acre. EDUFAC, Rio Branco, AC, Brasil.

18. Campos, M. A. A. 2008. Cruzando ecologia com os caçadores do Rio Cuieiras: saberes e estratégias de caça no Baixo Rio Negro, Amazonas. Dissertation. Instituto Nacional de Pesquisas da Amazônia, Universidade Federal do Amazonas, Manaus, Amazonas, Brasil.

19. Cardoso, E., S. Rodrigues-Filho, J. Costa and M. Guedes. 2013. Atividade de caça em uma comunidade na Reserva Extrativista do Rio Cajari, Amapá. In: Anais do XI Congresso de Ecologia do Brasil. Porto Seguro, Bahia, Brasil.

20. Chiarello, A. G. 2000. Influência da caça ilegal sobre mamíferos e aves das matas do tabuleiro do norte do estado do Espírito Santo. Boletim do Museu de Biologia Mello Leitão (11-12):229-247.

21. Coradini, F. R. and L. H. Cappelari, 2013. Apreensões de animais silvestres em Caçapava do Sul, Rio Grande do Sul - Brasil. Caderno de Pesquisa, série Biologia 24(3):6-12.

22. Costa-Neto, E. M. 2000. Conhecimento e usos tradicionais de recursos faunísticos por uma comunidade Afro-brasileira. resultados preliminares. Interciência 25(9):423-431.

23. Costa-Neto, E. M. 2011. A zooterapia popular no Estado da Bahia: registro de novas espécies animais utilizadas como recursos medicinais. Ciência \& Saúde Coletiva 16(Supl.1):1639-1650.

24. Cullen Jr., L., R. E. Bodmer and C. V. Pádua. 2000. Effects of hunting in habitat fragments of the Atlantic forests, Brazil. Biological Conservation 95:49-56.

25. Cullen Jr., L., R. E. Bodmer and C. V. Pádua, 2001. Ecological consequences of hunting in Atlantic forest patches, São Paulo, Brazil. Oryx. 35(2):137-144.

26. Dantas-Aguiar, P. R., R. M. Barreto, D. Santos-Fita and E. B. Santos. 2011. Hunting activities and wild fauna use: a profile of Queixo D'antas commnunity, Campo Formoso, Bahia, Brazil. Bioremediation, Biodiversity and Bioavailability 5(Special Issue I):34-43.

27. Dias Júnior, M. B. F., H. F. A. Cunha and T. C. A. C. Dias. 2014. Caracterização das apreensões de fauna silvestre no estado do Amapá, Amazônia Oriental, Brasil. Biota Amazônia 4(1):65-73.

28. Emídio-Silva, C. 1998. A caça de subsistência praticada pelos índios Parakanã (sudeste do Pará): características e sustentabilidade. Dissertation. Universidade Federal do Pará, Belém, Pará, Brasil.

29. Esteves, C. F. 2010. Influência antrópica na distribuição espacial da comunidade de mamíferos no Parque Estadual da Ilha Anchieta, SP. Dissertation. Universidade Estadual Paulista Júlio de Mesquita Filho, Instituto de Biociências, Rio Claro, São Paulo, Brasil.

30. Ferreira, D. S. S., C. E. C. Campos and A.S. Araújo. 2012. Aspectos da atividade de caça no Assentamento Rural Nova Canaã, município de Porto Grande, estado do Amapá. Biota Amazônia 2(1):22-31.

31. Ferreira, F. S., U. P. Albuquerque, H. D. M. Coutinho, W. O. Almeida and R. R. N. Alves, 2012. The trade in medicinal animals in Northeastern Brazil. Evidence-Based Complementary and Alternative Medicine 2012:1-20.

32. Flesher, K. M. and J. Laufer. 2013. Protecting wildlife in a heavily hunted biodiversity hotspot: a case study from the Atlantic Forest of Bahia, Brazil. Tropical Conservation Science 6 (2):181-200.

33. Fragoso, J. M. V., K. M. Silvius and M. Villa-Lobos. 2000. Wildlife management at the Rio das Mortes Xavante Reserve, MT, Brazil: Integrating indigenous culture and scientific method for conservation. World Wildlife Fund - Brazil, Brasilia, Brazil. 68p.

34. Fragoso, R. O., L. E. S. Delgado and L. M. Lopes. 2011. Aspectos da atividade de caça no Parque Nacional do Iguaçu, Paraná. Revista de Biologia Neotropical 8(1):41-52.

35. Fuccio, H., E. F. Carvalho and G. Vargas. 2003. Perfil da caça e dos caçadores no Estado do Acre, Brasil. Revista de Aportes Andinos, Movimientos Sociales, Políticas de Seguridad y Democracia 6:1-18.

36. Garcia, U. F. 2011. Ka’á Watá: “Andar na Floresta”: caça e território em grupo Tupi da Amazônia. Dossiê - Amazônia 17(1):172-190. 
37. Hanazaki, N., R. R. N. Alves and A. Begossi. 2009. Hunting and use of terrestrial fauna used by Caiçaras from the Atlantic Forest coast (Brazil). Journal of Ethnobiology and Ethnomedicine 5:1-36.

38. Hernandez, E. F. T. and Carvalho, M. S. 2006. O tráfico de animais silvestres no Estado do Paraná. Acta Scientiarum. Human and Social Sciences 28(2): 257-266.

39. Iwamura, T., E. F. Lambin, K. M. Silvius, J. B. Luzar and J. M. V. Fragoso. 2014. Agent-based modeling of hunting and subsistence agriculture on indigenous lands: Understanding between social and Ecological Systems. Environmental Modelling \& Software 58:109-127.

40. Leeuwenberg, F. J. and J.G. Robinson. 2000. Traditional management of hunting in a Xavante Community in central Brazil: the search for sustainability. Pages 375-394 In: Robinson, J. G., and E. L. Bennett, editors. Hunting for Sustainability in Tropical Forests. Columbia University Press, New York, USA.

41. Lopes, G. P., J. Valsecchi, T. M. Vieira, P. V. Amaral, and E. W. M. Costa. 2012. Hunting and hunters in lowland communities in the region of the middle Solimões, Amazonas, Brazil. Uakari 7(1):7-18.

42. Machado, F. S., J. C. C. Guimarães, L. A. C. Borges, J. L. P. Rezende and B. S. Corrêa. 2013. Será que a temática da caça no Brasil tem recebido a atenção necessária? Revista Agrogeoambiental 5(2):49-60.

43. Medeiros, M. F. S. T and L. G. Garcia. 2006. O consumo e as estratégias de caça utilizadas pelas populações tradicionais da Reserva Extrativista Chico Mendes. Interações 7(12):121-134.

44. Melo, E. R. A. 2012. O impacto da caça sobre a comunidade de mamíferos de médio e grande porte em Novo Paraíso, Roraima, norte da Amazônia brasileira. Dissertation. Universidade Federal de Pernambuco, Centro de Ciências Biológicas, Recife, Pernambuco, Brasil.

45. Melo, R. S., O. C. Silva, A. Souto, R. R. N. Alves and N. Schiel. 2014. The role of mammals in local communities living in conservation areas in the Northeast of Brazil: an ethnozoological approach. Tropical Conservation Science 7(3): 423-439.

46. Menegheti, J. O. 2005. Relatório final do programa de pesquisa e monitoramento de fauna cinegética do Rio Grande do Sul. Porto Alegre, Brasil. 36p.

47. Mesquita, E. D. S. 2004. Percepções e usos da fauna silvestre pelas comunidades humanas do entorno da Reserva Particular do Patrimônio Natural do Caraça, Catas Altas/Santa bárbara, MG. Dissertation. Pontifícia Universidade Católica de Minas Gerais, Belo Horizonte, Minas Gerais, Brazil.

48. Minzenberg, E. 2005. Hunting and household in PDS São Salvador, Acre, Brazil. Dissertation. University of Florida, Florida, USA.

49. Miranda, C. L. and G. S. Alencar. 2007. Aspectos da atividade de caça no Parque Nacional Serra da Capivara, Estado do Piauí, Brasil. Natureza \& Conservação 5(1):27-34.

50. Miranda, J. R. and J. A. C. Mangabeira. 2002. Extrativismo animal em zona de fronteira agrícola na Amazônia. EMBRAPA, Campinas, Brasil. 36 p.

51. Negreiros, A. B., F. P. Silva, and R.N. Lima. 2010. Percepção ambiental sobre a caça de animais silvestres: Diferentes visões na cidade de Floriano-PI. In: Anais do V Congresso Norte e Nordeste de Pesquisa e Inovação da Rede de Educação Tecnológica. Maceió, Alagoas, Brasil.

52. Neto, E. M. C. 2011. A zooterapia popular no Estado da Bahia: registro de novas espécies animais utilizadas como recursos medicinais. Ciência \& Saúde Coletiva 16:1639-1650.

53. Nobre, R. A. 2007. Modelos de sustentabilidade de caça de subsistência na Serra do Mar, Mata Atlântica. Dissertation. Escola Superior de Agricultura Luiz de Queiroz, Universidade de São Paulo, Piracicaba, São Paulo, Brasil.

54. Oliveira, E. S. 2011. Uso e conservação da fauna por populações humanas no Rio Grande do Norte, Nordeste do Brasil. Dissertation. Universidade Federal do Rio Grande do Norte, Natal, Rio Grande do Norte, Brasil.

55. Parry, L., J. Barlow and C. A. Peres. 2009. Allocation of hunting effort by Amazonian smallholders: Implications for conserving wildlife in mixed-use landscapes. Biological Conservation 142:1777-1786.

56. Parry, L., J. Barlow and H. Pereira. 2014. Wildlife harvest and consumption in Amazonia's urbanized wilderness. Conservation Letters 7:565-574. 
57. Pereira, J. P. R. and A. Schiavetti. 2010. Conhecimentos e usos da fauna cinegética pelos caçadores indígenas "Tupinambá de Olivença” (Bahia). Biota Neotropica 10(1):175-183.

58. Peres, C. A. and H. S. Nascimento. 2006. Impact of game hunting by the Kayapó of Southeastern Amazonia: Implications for wildlife conservation in tropical forest indigenous reserves. Biodiversity and Conservation 15:2627-2653.

59. Peres, C. A. and I. R. Lake. 2003. Extent of nontimber resource extraction in tropical forests: accessibility to game vertebrates by hunters in the Amazon Basin. Conservation Biology 17(2):521-535.

60. Peres, C. A. and E. Palacios. 2007. Basin-wide effects of game harvest on vertebrate population densities in Amazonian Forests: implications for animal-mediated seed dispersal. Biotropica 39(3):304-315.

61. Peres, C.A. 2000. Effects of subsistence hunting on vertebrate community structure in Amazonian Forests. Conservation Biology 14 (1):240-253.

62. Peres, C.A. 2001. Synergistic effects of subsistence hunting and habitat fragmentation on Amazonian forest vertebrates. Conservation Biology 15 (6):1490-1505.

63. Pessoa, T. S. A., P. G. C. Wagner and A. Langguth. 2013. Captura e comercialização de animais silvestres no semiárido da Paraiba, Brasil, sob a perspectiva de crianças e adolescentes. Revista Nordestina de Biologia 21(2):79-100.

64. Peters, F. B., P. R. O. Roth, M. S. Pereira, A. D. Piske and A.U. Christoff. 2011. Aspectos da caça e perseguição aplicada à mastofauna na área de proteção ambiental do Ibirapuitã, Rio Grande do Sul, Brasil. Biodiversidade Pampeana 9(1):16-19.

65. Pezzuti, J. and R. P. Chaves. 2009. Etnografia e manejo de recursos naturais pelos índios Deni, Amazonas, Brasil. Acta Amazônica 39(1):121-138.

66. Pianca, C. C. 2004. A caça e seus efeitos sobre a ocorrência de mamíferos de médio e grande porte em áreas preservadas da Mata Atlântica na Serra de Paranapiacaba (SP). Dissertation. Escola Superior de Agricultura Luiz de Queiroz, Universidade de São Paulo, Piracicaba, São Paulo, Brasil.

67. Pianca, C. C. 2001. Levantamento de mamíferos e sua caça em uma área preservada de Mata Atlântica no sudeste de São Paulo. Dissertation. Faculdade de Ciências Biológicas, Pontifícia Universidade Católica de São Paulo, Sorocaba, São Paulo, Brasil.

68. Pinto, L. L. C., M. B. Mateus and M. R. S. Pires. 2012. Conhecimentos e usos da fauna terrestre por moradores rurais da Serra do Ouro Branco, Minas Gerais, Brasil. Interciência 37(7): 520-527.

69. Prado, H. M. 2007. O impacto da caça versus a conservação de primatas numa comunidade indígena Guajá. Dissertation. Universidade de São Paulo, Instituto de Biociências, São Paulo, São Paulo, Brazil.

70. Prado, H. M., L. C. Forline, R. Kipnis. 2012. Hunting practices among the Awá-Guajá: towards a longterm analysis of sustainability in an Amazonian indigenous community. Boletim do Museu Paraense Emílio Goeldi 7(2):479-491.

71. Preuss, J. F. and P. F. Schaedler. 2011. Diagnóstico da fauna silvestre apreendida e resgatada pela polícia militar ambiental de São Miguel do Oeste, Santa Catarina, Brasil. Unoesc \& Ciência 2(2): 141-150.

72. Ramos, R. M. 2013. Caça de subsistência e conservação na Amazônia (Reserva Extrativista Rio Xingu, Terra do Meio, Pará): ecologia da caça e avaliação de impactos da caça. Dissertation. Universidade de Brasília, Brasília, Brasil.

73. Ramos, R. M; N. S. Carmo and J. C. B. Pezzuti, 2008. Caça e uso da fauna. Pages 224-232 In Monteiro, M. A., editor. Atlas socioambiental: municípios de Tomé-Açu, Aurora do Pará, Ipixuna do Pará, Paragominas e Ulianópolis. NAEA, Belém, Brasil.

74. Rocha-Mendes, F.; S. B. Mikich, G. V. Bianconi and W. A. Pedro. 2005. Mamíferos do município de Fênix, Paraná, Brasil: etnozoologia e conservação. Revista Brasileira de Zoologia 22(4):991-1002.

75. Rosas, G. K. C. and P. M. Drumond. 2007. Caracterização da caça de subsistência em dois seringais localizados no Estado do Acre (Amazônia, Brasil). Embrapa, Acre, Brasil. 31p.

76. Sampaio, D. R. 2011. A caça ilegal de animais silvestres na Mata Atlântica, Baixada litorânea do estado do Rio de Janeiro, Brasil: Eficiência de proteção de Reservas Biológicas e triangulação do perfil da caça. 
Dissertation. Universidade Estadual do Norte Fluminense Darcy Ribeiro, Campos dos Goytacazes, Rio de Janeiro, Brasil.

77. Sampaio, R. 2007. Efeitos a longo prazo da perda do habitat e da caça sobre mamíferos de médio e grande porte na Amazônia Central. Dissertation. Instituto Nacional de Pesquisas da Amazônia, Universidade Federal do Amazonas, Manaus, Amazonas, Brazil.

78. Sanches, A., P. M. Tokumoto, W. A. M. Peres, F. L. Nunes, M. S. T. Gotardi, C. S. Carvalho, C. Pelizzon, G. T Godoi and M. Galetti. 2012. Illegal hunting cases detected with molecular forensics in Brazil. Investigative Genetics 3(1):17.

79. Sarkis, F. 2002. Avaliação das condições microbiológicas de carnes de animais silvestres no Município de São Paulo. Dissertation. Escola Superior de Agricultura Luiz de Queiroz, Universidade de São Paulo, Piracicaba, São Paulo, Brasil.

80. Seixas, C. S. and A. Begossi. 2001. Ethnozoology of fishing communities from Ilha Grande (Atlantic Forest Coast, Brazil). Journal of Ethnobiology 21(1):107-135.

81. Silva, A. L. 2007. Comida de gente: preferências e tabus alimentares entre ribeirinhos do Médio Rio Negro (Amazonas, Brasil). Revista de Antropologia 50(1):125-179.

82. Silva, A. L. 2008. Animais medicinais: conhecimento e uso entre as populações ribeirinhas do rio Negro, Amazonas, Brasil. Boletim do Museu Paraense Emílio Goeldi. 3(3):343-357.

83. Silva, A.L., and A. Begossi. 2004. Uso dos recursos por ribeirinhos no médio Rio Negro. Pages 89-148 In: Begossi, A., editor. Ecologia de pescadores da Mata Atlântica e da Amazônia. Editora Hucitec, São Paulo, Brasil.

84. Smith, N. J. H. 1976. Utilization of game along Brazil's Transamazon highway. Acta Amazonica 6:455466.

85. Smith, N. J. H. 1978. Human exploitation of terra firme fauna in Amazonia. Ciência e Cultura 30:17-23.

86. Sousa, M.V.M. 2012. Sistemas socioecológicos em comunidades da Reserva Extrativista Chico Mendes e projeto de assentamento, na bacia hidrográfica do Riozinho do Rôla, Acre, Brasil: diagnóstico participativo sobre usos e impactos diferenciados sobre os recursos naturais. Dissertation. Instituto Nacional de Pesquisas da Amazônia, Manaus, Amazonas, Brasil.

87. Souza, J. B., and R. R. N Alves. 2014. Hunting and wildlife use in an Atlantic Forest remnant of northeastern Brazil. Tropical Conservation Science 7(1):145-160.

88. Souza-Mazurek, R.R.S., T. Pedrinho, X. Feliciano, W. Hilário, S. Gerôncio, and E. Marcelo. 2000. Subsistence hunting among the Waimiri Atroari Indians in central Amazonia, Brazil. Biodiversity and Conservation 9:579-596.

89. Strong, J. N., J. M. V. Fragoso, and L.F.B. Oliveira. 2010. Padrões de uso e escolha de caça pelos Índios Macuxi em Roraima. Pages 631-644 In: Barbosa, R. I. and V. F. Melo, editors. Roraima: Homem, ambiente e ecologia. Fundação Estadual do Meio Ambiente, Ciência e Tecnologia, Roraima, Brasil.

90. Terra, A. K., and G. H. Rebêlo. 2005. O uso da fauna pelos moradores da Comunidade São João e Colônia Central. Pages 141-153 In: Nelson, E., F. Marques, V. Vizoni and S. Melo, editors. Biotupé: Meio Físico, Diversidade Biológica e Sociocultural do Baixo Rio Negro, Amazônia Central. INPA, Manaus, Brasil.

91. Travassos, L. 2011. Impacto da sobrecaça em populações de mamíferos e suas interações ecológicas nas florestas neotropicais. Oecologia Australis 15(2):380-411.

92. Trinca, C. C. 2004. Caça em assentamento rural no sul da floresta amazônica. Dissertation. Museu Paraense Emílio Goeldi, Universidade Federal do Pará, Belém, Pará, Brasil.

93. Trinca, C. T., and S. F. Ferrari. 2007. Game populations and hunting pressure on a rural frontier in Southern Brazilian Amazonia. Biologia Geral e Experimental 7: 5-16.

94. Trinca, C. T., and S. F. Ferrari. 2005. Caça em assentamento rural na Amazônia matogrossense. Pages 155-167. In: Jacobi, P. and L. C. Ferreira, editors. Diálogos em ambiente e sociedade no Brasil. ANPPAS, Indaiatuba, Brasil.

95. Valsecchi, J., and P. V. Amaral. 2009. Perfil da caça e dos caçadores na Reserva de Desenvolvimento Sustentável Amanã, Amazonas - Brasil. Uakari 5(2):33-48. 
96. Valsecchi, J., H. R. El Bizri, and J. E. C. Figueira. 2014. Subsistence hunting of Cuniculus paca in the middle of the Solimões River, Amazonas, Brazil. Brazilian Journal of Biology 74(3): 560-568.

97. van Vliet, N., M. P. Quiceno-Mesa, D. Cruz-Antia, C. Morsello, C. Adams, F. Mori, B. Yagüe, S. Hernández, T. Bonilla, L. Tellez, L. J. N. Aquino, J. Moreno, T. Schor, M. O. Princi, E. Haiden, F. Trujillo, and R. Nasi. 2014. Bushmeat in the tri-frontier region of Brazil, Peru and Colombia: Demise or persistence? Center for International Forestry Research (CIFOR), Bogor, Indonesia.

98. van Vliet, N., M. P. Quiceno-Mesa, D. Cruz-Antia, L. J. N. Aquino, J. Moreno, and R. Nasi. 2014. The uncovered volumes of bushemeat commercialized in the Amazonian trifrontier between Colombia, Peru \& Brazil. Ethnobiology and Conservation 3:7.

99. Vasconcelos Neto, C. F. A., S. S. Santos, R. F. Sousa, H. Fernandes-Ferreira, and R. F. P. Lucena. 2012. A caça com cães (Canis lupus familiaris) em uma região do semiárido do nordeste do Brasil. Revista de Biologia e Farmácia Special Volume: 1-16.

100.Velthem Linke, I. H. V. 2009. Caracterização do uso da fauna cinegética em aldeias das etnias Wayana e Aparai na terra indígena parque do Tumucumaque, Pará. Dissertation. Universidade Federal do Pará, Museu Paraense Emílio Goeldi, Belém, Pará, Brasil.

101.Villalobos, M. P. 2002. Efeito do fogo e da caça na abundância de mamíferos na reserva Xavante do Rio das Mortes, MT, Brasil. Dissertation. Universidade de Brasília, Instituto de Ciências Biológicas, Brasília, Distrito Federal, Brasil.

102.Von Mühlen, E. M. 2005. Consumo de proteína animal em aldeias de terra firme e de várzea da terra indígena Uaçá, Amapá, Brasil. Dissertation. Universidade Federal do Pará, Museu Paraense Emílio Goeldi, Belém, Pará, Brasil.

103.Welch, J. R. 2014. Xavante ritual hunting: anthropogenic fire, reciprocity, and collective landscape management in the Brazilian Cerrado. Human Ecology 42(1):47-59.

104.Zimmerman, B., C. A. Peres, J. R. Malcolm and T. Turner. 2001. Conservation and development alliances with the Kayapó of south-eastern Amazonia, a tropical forest indigenous people. Environmental Conservation 28(1):10-22. 